\title{
Well-Being in the Small and in the Large
}

\author{
Andrew K. Rose
}

Is it better to live in a big country than a small one? In this paper, I examine whether economic and social conditions vary systematically with the population of a country. Economics provides a number of theoretical reasons why country size should matter, for instance, because of increasing returns to scale or because it is easier to provide public goods to a larger populace. However, there is little empirical evidence linking the scale of country size to any of a multitude of indicators of economic and social welfare.

Keywords: Population; Empirical; Data; National; Country; Scale; Size JEL Classification: 057

B. T. Rocca Jr. Professor of International Business, Haas School of Business, University of California, Berkeley (E-mail: arose@haas.berkeley.edu; website: http//faculty.haas.berkeley.edu/arose)

This paper was prepared in part while the author was a visiting scholar at the Institute for Monetary and Economic Studies (IMES), Bank of Japan (BOJ). The author would like to thank the IMES at the BOJ and the Hong Kong Institute for Monetary Research for hospitality, and an anonymous referee, Naohiko Baba, and workshop participants at the IMES for comments. This paper is closely related to the author's other work, especially Rose (2006). The dataset, key output, and a current version of the paper are available at the author's website. Views expressed in this paper are those of the author and do not necessarily reflect the official views of the BOJ. 


\section{Introduction}

In this paper, I examine whether well-being-by which I mean the welfare of the average person-is systematically higher in countries that have larger populations.

Common sense indicates that the answer to this question should be resoundingly negative. After all, China and India are large and poor, while the quality of life is higher in small, rich countries such as Luxembourg and Singapore. Still, there are at least three reasons to be interested in this question. First, much of modern economics-indeed, much of the trendiest work in macroeconomics-turns out to assume that the size of a country matters. Second, this question has essentially been left unanswered in the literature. While the first two points are of great academic (that is to say, negligible) interest, the third is not: if larger countries were in fact found to be systematically better off than smaller countries, this finding would have dramatic policy implications. Small countries would be systematically and perhaps unconsciously sacrificing the welfare of their citizens by remaining small. A finding that "the whole is greater than the sum of the parts" would be important, since it would lead to the policy conclusion that small countries should consider joining together into larger ones to improve the quality of life of their citizens. On the other hand, if welfare is systematically lower in large countries, then just the opposite is suggested.

Fortunately, I find that folk wisdom is indeed confirmed. There seems to be no relationship between a country's size and a wide variety of measures of its social and economic well-being. For policymakers and nationalists, this is a good outcome; there is no obvious economic or social price that small countries pay simply by being small. But it is worse news for academic economists who assume that the scale of economic activity matters.

\section{Motivation}

Before diving into the actual empirical analysis, it is worthwhile to describe briefly why this exercise is worth undertaking. There is actually a lot of motivation for a study of the effects of size on economic well-being, since so many economists assume that a large country has intrinsic advantages over an otherwise similar but smaller country. There are two strands of thought on why this is so. The more important is the possibility of increasing returns to scale in production, which means that agents are more productive when combined. Another possibility is that it may be cheaper for the government to provide public goods in a larger state than in a smaller state. I now briefly review each of these strands of thinking. But those sufficiently motivated already can skip this section altogether and simply proceed to the analysis in Section III.

\section{A. Increasing Returns to Scale}

The literature on scale effects in economics has a long and glorious history. Indeed, it stretches back all the way to Adam Smith's idea that the specialization of labor is limited by the extent of the market. Indeed, Smith begins the first chapter of the first book of the most famous work in economics (The Wealth of Nations) with 
"The greatest improvement in the productive powers of labour... seem[s] to have been the effects of the division of labour." He continues with a chapter entitled "That the Division of Labour is Limited by the Extent of the Market," which begins:

As it is the power of exchanging that gives occasion to the division of labour, so the extent of this division must always be limited by the extent of that power, or, in other words, by the extent of the market. When the market is very small, no person can have any encouragement to dedicate himself entirely to one employment, for want of the power to exchange all that surplus part of the produce of his own labour, which is over and above his own consumption, for such parts of the produce of other men's labour as he has occasion for. ${ }^{I}$

This idea has been formalized and used in much recent economics. Helpman and Krugman (1985) provide a celebrated analysis of the impact of increasing returns on international trade. They discuss two kinds of economies of scale, which can be either internal or external to the firm. Internal scale economies can be due to things like the length of plant runs; since it takes resources to reconfigure a car factory, the longer a factory produces a given model of car, the cheaper the car. Internal scale economies can also be dynamic, since learning by doing can occur over time.

But scale economies can also be outside the scope of a firm but internal to an industry. For instance, intermediate inputs might be cheaper and more specialized for larger industries. Large industries might also be more competitive than small ones. There is only room for a few defense contractors even for a large country, which explains why the submarine market is less competitive than the market for pizza. Information also might spill over from one firm to another; isolated software makers do not tend to be prosperous. Alternatively, a wider range of tastes is supported by a larger populace, which explains why small towns tend to be more homogeneous than large cities. These are examples of "agglomeration effects," which occur when a group of agents acting together are better off than when they are spread out. Agglomeration effects have long been a part of urban economics; it is hard to explain the existence of massive cities like Tokyo and Mexico City without agglomeration effects. An excellent introduction to such issues and the economic geography is provided by Fujita, Krugman, and Venables (1999).

Scale effects need not just have an effect on the level of output; they can also affect growth. Indeed, much recent work in growth theory has formalized scale effects. Many models rely on learning by doing and/or knowledge spillovers, and result in the conclusion that larger countries should grow faster: Barro and Sala-i-Martin (1995) provide a general treatment. Indeed, scale effects are generic to endogenous growth models (Aghion and Howitt [1998, p. 28]). Jones (1999, p. 143) discusses three classes of endogenous growth models and shows that they all have a scale effect: "the size of the economy affects either the long-run growth rate or the long-run level of per capita income" since larger countries can support more research, which delivers a higher level or growth rate of productivity.

1. Book I, Chapter III of An Inquiry into the Nature and Causes of the Wealth of Nations. Thomas Malthus was concerned about population growth rather than size per se, although the two are obviously related. 


\section{B. More Effective Public Services}

There are a host of sensible theoretical reasons why economies of scale might exist at the national level. But larger countries can be better off than smaller nations even without any scale economies. The reason is that governments take an active role in providing services to the public; governments of large countries may be able to do this more effectively than their counterparts in smaller countries.

In their recent book, Alesina and Spolaore (2003) list a number of different benefits of large population size; many involve lower per capita costs of providing public goods. For instance, there is a certain degree of indivisibility in a medical system; surgeons who specialize in particular operations are better than generalists. Thus, smaller countries might be expected to be less efficient in providing health care. Similarly, maintaining an educational system involves equipping a set of schools and universities; if some of these costs are independent of scale, then they would be cheaper in larger countries. Providing an efficient tax system and/or national defense might also plausibly involve scale economies. Finally, larger countries might have a greater ability to provide either regional insurance or income redistribution.

Succinctly, there are a host of reasons to expect governments of larger countries to be able to do their work more effectively than governments in smaller countries.

\section{The Costs of Diversity in Large Countries}

The quick survey above shows that there is plenty of reason to believe that larger countries have theoretical advantages over smaller ones. Still, Alesina and Spolaore (2003) argue that there is a downside to these benefits: larger countries can be expected to have more diverse preferences, cultures, and languages. They state that "on balance, heterogeneity of preferences tends to bring about political and economic costs that are traded off against the benefits of size" (p. 6). Their reasoning is not new and follows a number of great thinkers. For instance, in Chapter XVII of the Leviathan, Thomas Hobbes argued that small populations were insufficient to deter invasion and provide security, while excessively large countries would be incapable of the common defense because of lack of a common purpose and internal distractions. Similarly, Olson (1982) argues that small homogenous societies are less burdened by the logic of collective action and have more capacity to create prosperity.

The question I ask in this paper is: do any of these effects (increasing returns/ cheaper public goods/heterogeneity) exist at the national level? All of these effects might be important at the sub-national level without there being any discernible national "scale effect." I now start to investigate this question.

\section{A Naive Approach}

My empirical strategy is to examine the relationships between a country's size and a host of economic and social phenomena suggested by the literature. The literature suggests that economies of scale may be a key advantage of larger countries, so I examine a number of different measures of economic well-being. But I do not restrict myself to narrow economic measures. Key services (such as health and education) are 
not only standard indicators of development that are important in themselves, but are also often provided by the public sector. As part of my broad-brush approach, I also look at noneconomic measures of well-being such as political and civil rights. Finally, I also search for indications that larger countries might suffer the costs of higher diversity, as suggested by Alesina and Spolaore (2003).

It is worth emphasizing at the outset that my focus is narrow; it is on the effects of national scale on various phenomena, not of changes in a country's size. Clearly countries grow at different rates; understanding the causes and consequences of growth across countries and time is an area of enormous importance that has (appropriately) been studied by hundreds of scholars. My interest is on the effects of differing country size and is thus appropriately conducted through largely cross-sectional analysis (although I consider different points of time). ${ }^{2}$ I defer consideration of more dynamic considerations of the growth of country size to future research.

I start with a simple graphical approach. A simple scatter-plot of one variable against another can be misleading in a number of ways. Many of these can be fixed with a more sophisticated statistical approach, so it is important not to stop after drawing some pictures. Accordingly, I use more advanced econometric firepower in the section that follows.

I begin my search for an effect of scale in the most natural place possible (at least for an economist): by looking at output. More precisely, I compare real GDP per capita (adjusted for deviations from purchasing power parity [PPP]) to population. Since my interest is in comparing small and large countries, I look across countries (rather than looking at one country over different periods of time; more on that below). Figure 1 provides a scatter-plot of the natural logarithm of real GDP per capita against the log of population. I use all 168 "countries" for which both series are available, each marked with a dot. ${ }^{3}$ A list of all the countries that I consider in the paper is provided in Appendix Table 1. The population and output data themselves are taken from the widely used and reliable World Development Indicators provided by the World Bank. A complete set of data sources is tabulated in Appendix Table 2, and the data set is summarized in Appendix Table 3 (and is freely available at my website). A fitted regression line is also provided in the figure.

A person could reasonably characterize the relationship portrayed in Figure 1 between (the logs of) real GDP per capita and population as nonexistent. Indeed,

2. More technically, I am interested in the effect of scale between different countries, rather than the effect of a change in scale for a single country (or set of countries). For panel analysis that focuses on the "within" rather than just "between" estimator, the reader is referred to Rose (2006). When one does use country-specific fixed effects, the results are basically consistent. Only six of the measures I consider have significant size effects with fixed-effects panel estimation. Two of these indicate a "correctly signed" (positive) scale effect (life expectancy and infant mortality), while four go the "wrong way" (real GDP per capita, vehicles, televisions, and political rights). The rest are either insignificantly different from zero or inestimable. When I add lagged real GDP per capita to the controls, none of the scale-effect coefficients are significantly different from zero at conventional levels.

3. I am skipping over an unimportant but interesting underlying issue here: there is no universal definition of a "country." Economists often ignore places such as Niue, a small island in the South Pacific that has been selfgoverning in free association with New Zealand since 1974 and had an estimated 2005 population of 2,166. Is Niue really a "country"? Nauru has no military forces, currency, or U.S. embassy, but is a member of the United Nations. Is it a "country"? If not, what about Tonga, home to just over 110,000 people? Luxembourg, with fewer than half a million, or Slovenia, with two million? If one must draw the line, where should it be, and why? My default is to consider as "countries" all entities referred to as such by the World Development Indicators (WDI) in 2005. Further discussion is available in Rose (2006). 
Figure 1 Income and Country Size

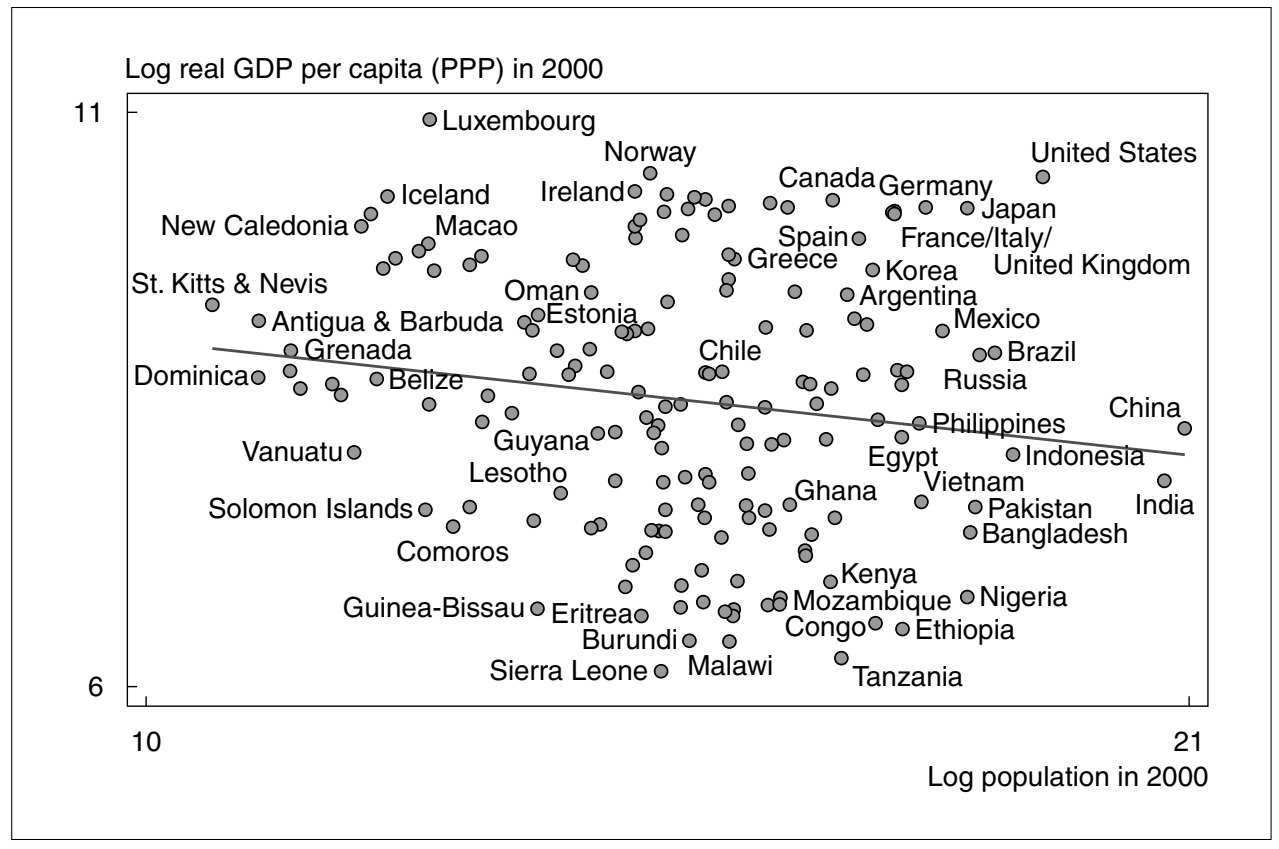

if anything the relationship is slightly negative (although the statistical significance of this is marginal). There are obviously some rich large countries; the United States, Japan, and indeed the rest of the G-7 countries come to mind quickly. But there are also poor large countries (such as Bangladesh and Nigeria) and a number of rich small countries (such as Luxembourg and Iceland). Moreover, the relationship is not obviously dominated by either some nonlinear relationship or a couple of large poor outlier countries, such as China and India. ${ }^{4}$ Rather, the data just seem to be a cloud.

Indeed, probably the most striking feature of Figure 1 is just how different countries are, in terms of both real output per head and population. In 2000, there were over 28,000 Chinese for each of citizen of St. Kitts and Nevis. While average annual GDP per capita in Sierra Leone was less than US\$475, the equivalent in Luxembourg was over 100 times higher; two orders of magnitude! But while both size and real output per person varied widely, they did not vary together systematically, certainly not in the positive manner predicted by many economists.

One might be tempted to ask if I am just defining size in an unusual way. But I am not; a country's population is the standard measure of a country's size. This partly reflects the fact that we care almost exclusively about the well-being of people (not, for instance, capital). Labor is also the most important factor of production. Of course, it is not the only factor of production, and population is not the only measure of country size. But other measures of country size deliver much the same message. For instance, Appendix Figure 1 is an analogue to Figure 1 but uses (the natural logarithm

4. Indeed, all the results below hold true if I drop India and China from the sample. I also note in passing that using locally weighted regressions instead of ordinary least squares (OLS) to estimate the regression also results in a similarly weak, somewhat negative, relationship between log real GDP per capita and log population. 
of) total country area instead of population. The finding is the same; the size of a country is basically unrelated to income per person. ${ }^{5}$ If anything, countries that are geographically larger tend to be somewhat poorer than smaller nations. ${ }^{6}$

If economies of scale were the only reason to expect a national scale effect, then this evidence might be sufficient to persuade one of the unimportance of country size. But even if scale economies are unimportant at the national level, the public finance arguments still have a ring of plausibility. And economists tend to fixate on GDP excessively. Accordingly, I now examine two of the most important services that governments typically deliver worldwide: health and education. These are not only relevant to the case for scale economies, but are of great intrinsic importance.

Figure 2 is a set of six small cross-sectional scatter-plots. Each is similar to Figure 1 in that a variable is plotted against (the natural logarithm of) population, with individual points representing countries; thus, China is always the observation at the extreme right-hand side of the graph, with India next to it. Each has a linear regression line displayed to show the general tendency of the data. And, as in Figure 1, each graph shows the "wrong" relationship between size and well-being!

\section{Figure 2 Health, Education, and Country Size}

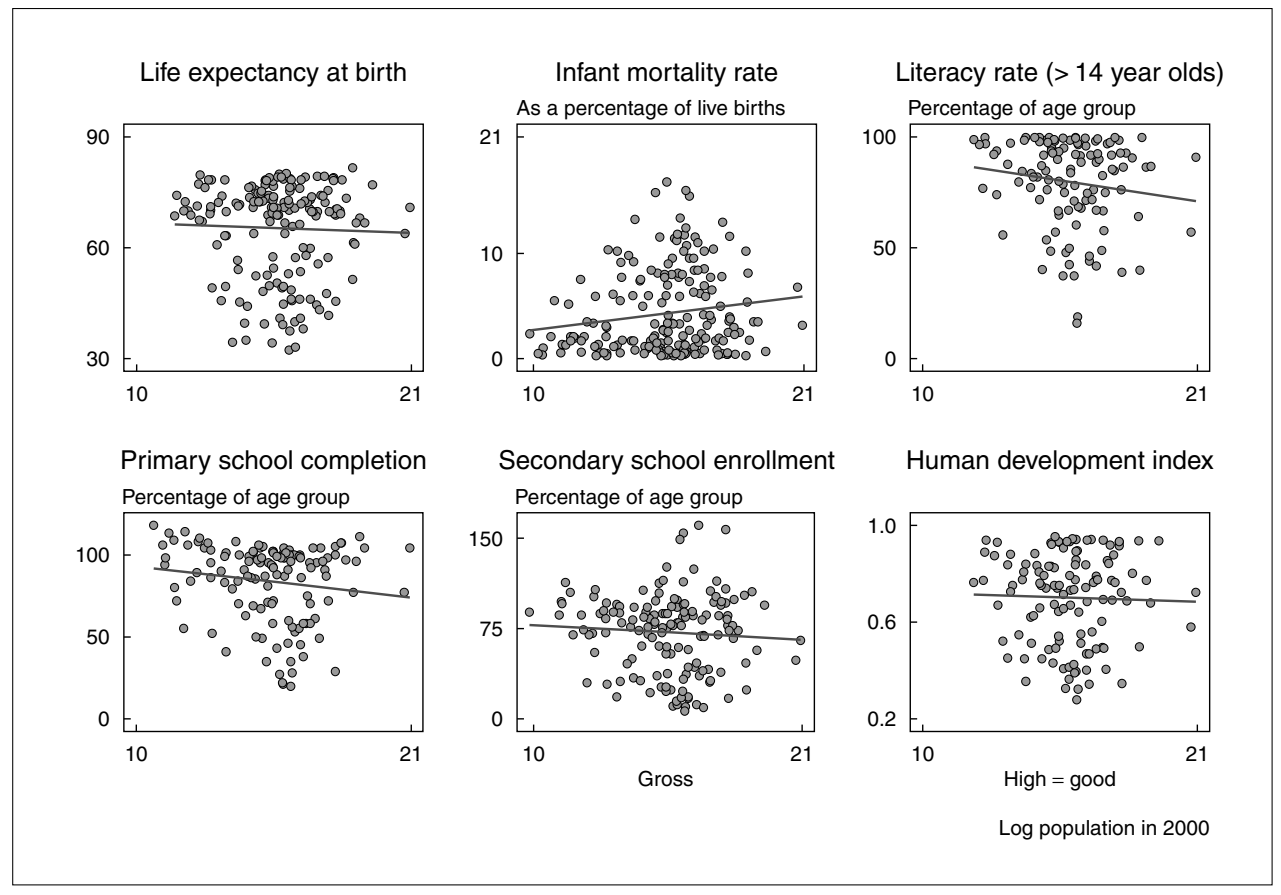

5. This is not particularly surprising, since most measures of country size are highly (positively) correlated. For instance, in 2000 the correlation between the natural logarithms of countries' surface areas and populations was 0.84 .

6. Is Figure 1 a blur simply because it is a simple bivariate scatter-plot? Perhaps controlling for other determinants of income might produce a sharp positive relationship? Sadly, Appendix Figure 2 tests and rejects this idea. It is an analogue to Figure 1 but graphs the residual of a linear regression of log output on 29 controls against the residual of a regression of log population on the same 29 controls. The data still resemble a cloud with a slight downward tilt. More details on the regression analysis are provided in the section below. 
I begin by considering two standard measures of a country's health: the life expectancy of a newborn baby (in years), and the infant mortality rate (as a percentage of live births). Neither shows any strong relationship to country size; if anything, life expectancy tends to be (slightly) lower in larger countries, while the infant mortality rate is higher. Standard measures of education give the same impression. The literacy rate for adults over the age of 14 is somewhat lower in large countries. The same is true of the percentage (of the relevant age group) that has completed primary school, or is enrolled in secondary school. Such measures of health and education are sometimes combined with output by the United Nations Development Program (UNDP) into a composite "human development index," which is also graphed against size at the bottom right of Figure 2. Higher values of the human development index are equated with higher well-being. ${ }^{7}$ But the human development index is somewhat negatively correlated with country size.

GDP is a somewhat abstract notion. Perhaps the advantages of size are more apparent when one focuses on more direct measures of economic well-being. I do this in Figure 3, with another series of small graphs. From the top-left corner of the figure, I scatter three types of material possessions against (the natural logarithm of) population: vehicles, televisions, and telephones. All are measured in per capita terms, the former two in 2000, while the latter is only available for 1990 . There is again no evidence that larger countries find it easier to provide such objects to their citizens; all three pictures are blurry, but point to size disadvantages.

Figure 3 Material Well-Being, Institutions, and Country Size

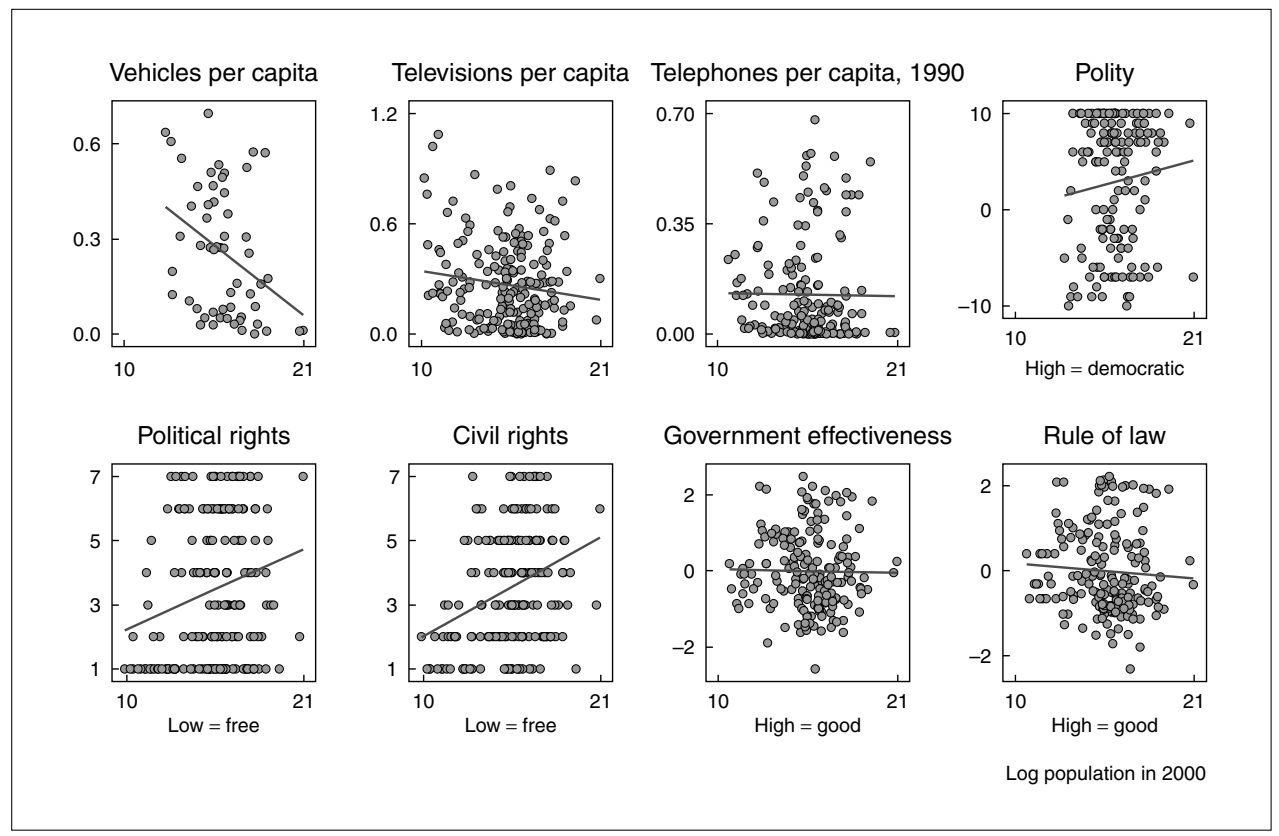

7. The UNDP provides more on human development at http://hdr.undp.org/hd/. 
Even if larger countries do not provide more possessions to their citizens, they still may offer a higher quality of life. For instance, larger countries might be systematically more democratic or free. Are they? I provide three graphs of relevance in Figure 3. The democratic nature of the political regime is measured with the standard "polity" variable taken from the Polity IV project at the University of Maryland; a score of +10 represents the highest score possible for a democracy, while a score of -10 represents a total autocracy. Freedom House measures political and civil rights for a large number of countries; a rating of one indicates the highest degree of freedom, while seven indicates the least amount of freedom. ${ }^{8}$ I display scatter-plots of both political and civil rights against $(\log )$ population in Figure 3.

The good news is that there is a slight tendency for large countries to be more democratic than smaller countries; the line in the "polity" graph slopes upward (although not at a level that is significantly different from zero). But both political and civil rights are lower in larger countries, and sadly both of these effects are significantly different from zero. Further, these slopes are not dominated by a few unusual countries whose "outlier" observations dominate the picture. There is just no evidence that citizens of larger countries enjoy more liberty than their counterparts in smaller countries.

Figure 2 showed that larger countries did not systematically display better health or educational outcomes. But governments of larger countries might have used smaller inputs to deliver output; that is, they might be systematically more productive than governments in smaller countries. Are they? To test this idea, I use the data set of Kaufmann, Kraay, and Zoido-Lobaton (1999), who provide a number of measures that quantify governance across countries; I use "government effectiveness." This concerns the quality of public service provision and the bureaucracy, the competence of civil servants, the independence of the civil service from political pressures, and the credibility of the government's commitment to policies. I also portray their measure of "rule of law," which measures the extent to which agents have confidence in and abide by the rules of society, including perceptions of the incidence of crime, the effectiveness and predictability of the judiciary, and the enforceability of contracts. Government effectiveness and the rule of law are graphed separately against (log) population at the bottom right corner of Figure 3; higher values indicate better governance. But both are slightly negatively correlated with a country's size. To sum up: there are few signs of a scale advantage.'

Larger countries do not seem systematically richer, healthier, better educated, safer, or freer. But if there are no advantages to size, are there disadvantages such as the increased diversity highlighted by Alesina and Spolaore (2003)? This question deserves attention.

In Figure 4, I graph four different measures of national diversity against population. The first measure is "ethno-linguistic fractionalization," a measure introduced into

8. While it is undoubtedly true that there are errors in measuring political measures such as political rights or democracy, the same is true of economic variables. Further, measurement error in the dependent variable does not result in nearly the level of econometric difficulties as it would if we were to use these variables as regressors.

9. These negative results are consistent with those of Perkins and Syrquin (1989), who basically only find a strong (negative) effect of size on trade. 
Figure 4 Diversity and Country Size

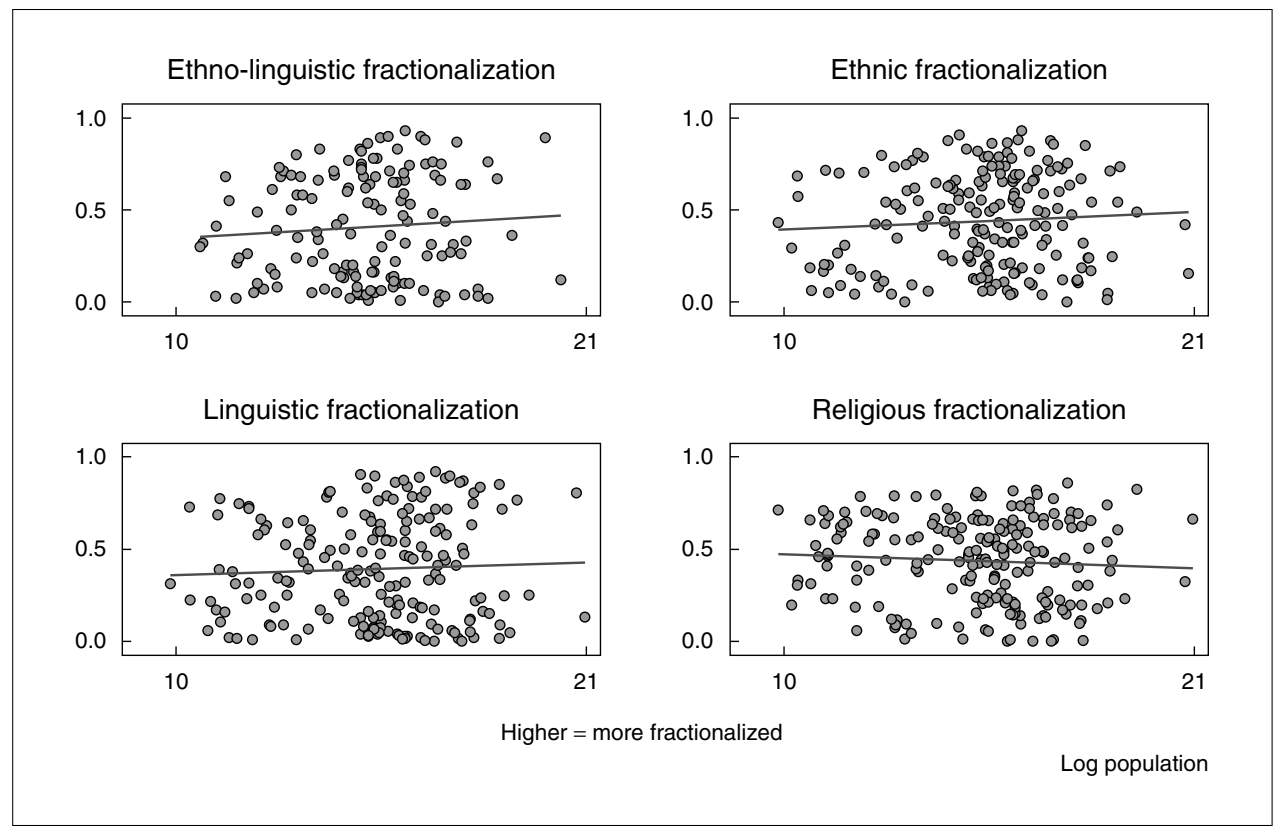

economics by Mauro (1995). The index was constructed by researchers from the Soviet Union and attempts to quantify the probability that two randomly chosen people will not have the same language, given the number of ethnic groups in the country. A higher value indicates more fractionalization. This has been much analyzed in economics of late. It has also been updated by Alesina et al. (2003), who provide more precise but otherwise analogous measures for a large number of countries on ethnic, linguistic, and religious fractionalization. Accordingly, Figure 4 also exploits the three new measures of Alesina et al. (2003), above and beyond the classic ethno-linguistic measure of fractionalization.

The graphs show curiously little evidence of a strong positive relationship between a country's size and its diversity. The relationships are positive for three out of the four measures of diversity, but are never strong or statistically significant. Religious fractionalization is actually negatively (although not significantly) correlated with population! As with the other variables I have examined, the most striking feature is the diversity across countries, not the links to country size. A moment's reflection indicates the common-sense nature of this finding. Some countries that are large are diverse (e.g., India and Indonesia); others are relatively homogeneous (e.g., China and Japan). Country size seems not to be tightly tied to national diversity.

To summarize, my naive first look at the data has not revealed compelling evidence that larger countries are either advantaged because of their economic mass or disadvantaged because of diversity. I now show that these results are not simply the result of a simplistic graphical approach, but instead reflect deeper features of the data. 


\section{A More Sophisticated Approach}

The graphical results of the preceding section can be criticized in a number of ways. Perhaps most importantly, the pictures are bivariate and do not take into account the multitude of other factors that might affect the relationship between well-being and size. After taking these other influences into account, it might be possible to see the advantages of size more clearly. Further, the graphs were cross-sectional and did not take into account the fact that some variables are available for a number of different years (as well as a number of different countries). Finally, some third force might be causing population and the variables of interest to move simultaneously. ${ }^{10}$

Accordingly, I now pursue econometric analysis that is complementary to that of the graphics of the preceding section. I estimate a set of linear regressions, three for each variable of interest. The first is a simple regression of the dependent variable on the natural logarithm of population. The second (like the first, estimated with ordinary least squares [OLS]) includes a large number of control variables to hold other factors constant when interpreting the coefficient for the size effect. The third uses an instrumental variable (IV) estimator to account for the possibility that population and the economic/social outcomes I consider are jointly determined. I use the log of total country area as an IV for the log of population. ${ }^{I I} \mathrm{I}$ interpret my regression results as being nonstructural (since I do not wish to rely on a single structural model); they are simply partial correlation coefficients that indicate whether there is any strong association of country size with other phenomena. The presence of such correlations would warrant further investigation, but the absence of such correlations is bad news for advocates of a national scale effect.

Observations are often available for a number of different years (not just 2000). Accordingly, I pool data sampled at decadal intervals over all the available years, and include year-specific intercepts. Analogous panel analysis that accounts for countryspecific fixed effects is contained in Rose (2006).

I tabulate in Table 1 the coefficient of interest (denoted $\beta$ ) estimated from

$$
y_{i t}=\beta \ln \left(P o p_{i t}\right)+\alpha+\left\{\gamma_{t} T_{t}\right\}+\sum_{j} \delta_{j} X_{i j t}+\epsilon_{i t},
$$

where $y$ is a dependent variable of interest for country $i$ at year $t$, such as real GDP per capita, Pop denotes population, $\left\{T_{t}\right\}$ denotes a mutually exclusive and jointly exhaustive set of time-specific fixed effects, $\left\{X_{j}\right\}$ denotes a set of control variables. $\epsilon$ is a well-behaved residual, and $\alpha,\{\gamma\},\{\delta\}$ are nuisance coefficients.

Table 1 records the slope coefficient on country size, along with a robust standard error. I mark coefficients statistically significant at the 5 percent (1 percent) level with one (two) asterisk(s). There are 19 rows, one for each of the variables graphed against country size in the figures. There are also three columns: the "simple" coefficients correspond to the bivariate model so that $\{\delta\}=0$; the "with controls"

10. Alesina and Spolaore (2003) argue that a country's size might vary systematically because of economic circumstances. However, Drazen (2000) argues forcefully that there seems to be little empirical content in this argument.

11. Log area seems to work well as an IV for log population. The coefficient on log area in the first stage has a robust $t$-statistic of 9.7 , and the $\mathrm{R}^{2}$ is over 0.8 . 
Table 1 Regression Results

\begin{tabular}{|c|c|c|c|}
\hline $\begin{array}{l}\text { Dependent } \\
\text { variable }\end{array}$ & $\begin{array}{l}\text { OLS } \\
\text { bivariate }\end{array}$ & $\begin{array}{l}\text { OLS with } \\
\text { controls }\end{array}$ & $\begin{array}{l}\text { IV with } \\
\text { controls }\end{array}$ \\
\hline $\begin{array}{l}\text { Log real GDP per capita } \\
\text { (at PPP exchange rates) }\end{array}$ & $\begin{array}{l}-0.07 \\
(0.04)\end{array}$ & $\begin{aligned}-0.07^{\star} \\
(0.03)\end{aligned}$ & $\begin{array}{l}-0.06 \\
(0.04)\end{array}$ \\
\hline Life expectancy at birth & $\begin{array}{c}0.10 \\
(0.39)\end{array}$ & $\begin{array}{c}0.02 \\
(0.24)\end{array}$ & $\begin{array}{l}-0.50 \\
(0.44)\end{array}$ \\
\hline Infant mortality rate & $\begin{array}{c}1.1 \\
(1.5)\end{array}$ & $\begin{array}{c}-1.04 \\
(1.06)\end{array}$ & $\begin{array}{l}-0.08 \\
(1.47)\end{array}$ \\
\hline Literacy rate $(>14)$ & $\begin{array}{c}-1.8 \\
(1.0)\end{array}$ & $\begin{array}{l}0.74 \\
(0.78)\end{array}$ & $\begin{array}{c}0.08 \\
(0.95)\end{array}$ \\
\hline Primary school completion rate & $\begin{array}{c}-1.2 \\
(1.1)\end{array}$ & $\begin{array}{c}0.49 \\
(1.10)\end{array}$ & $\begin{array}{l}-0.28 \\
(1.43)\end{array}$ \\
\hline Secondary school enrollment rate & $\begin{array}{l}-0.45 \\
(1.0)\end{array}$ & $\begin{array}{c}0.78 \\
(0.96) \\
\end{array}$ & $\begin{array}{c}1.43 \\
(1.45) \\
\end{array}$ \\
\hline Human development index & $\begin{array}{l}-0.01 \\
(0.01)\end{array}$ & $\begin{array}{c}-0.004 \\
(0.004)\end{array}$ & $\begin{array}{c}-0.004 \\
(0.008) \\
\end{array}$ \\
\hline Vehicles per capita & $\begin{array}{c}-7.6 \\
(10.3)\end{array}$ & $\begin{array}{l}-5.6 \\
(5.4) \\
\end{array}$ & $\begin{array}{l}11.6 \\
(8.8) \\
\end{array}$ \\
\hline Telephones per capita & $\begin{array}{c}-0.92 \\
(6.1)\end{array}$ & $\begin{array}{l}-3.8 \\
(3.3) \\
\end{array}$ & $\begin{array}{c}2.5 \\
(5.8) \\
\end{array}$ \\
\hline Televisions per capita & $\begin{array}{c}-9.3 \\
(7.2) \\
\end{array}$ & $\begin{array}{c}2.3 \\
(4.8) \\
\end{array}$ & $\begin{array}{c}-7.2 \\
(8.0) \\
\end{array}$ \\
\hline Polity (high = democratic) & $\begin{array}{l}0.56 \\
(0.38)\end{array}$ & $\begin{array}{l}0.40 \\
(0.26)\end{array}$ & $\begin{array}{l}0.96^{*} \\
(0.46)\end{array}$ \\
\hline Political rights $($ low $=$ free $)$ & $\begin{array}{l}0.13 \\
(0.07)\end{array}$ & $\begin{array}{l}-0.02 \\
(0.06)\end{array}$ & $\begin{array}{l}-0.13 \\
(0.08)\end{array}$ \\
\hline Civil rights $($ low $=$ free $)$ & $\begin{array}{l}0.18^{\star \star} \\
(0.06)\end{array}$ & $\begin{array}{l}0.02 \\
(0.05)\end{array}$ & $\begin{array}{l}-0.06 \\
(0.07)\end{array}$ \\
\hline $\begin{array}{l}\text { Government effectiveness } \\
\text { (higher = better) }\end{array}$ & $\begin{array}{c}-0.01 \\
(0.03)\end{array}$ & $\begin{array}{c}-0.01 \\
(0.04)\end{array}$ & $\begin{array}{l}0.04 \\
(0.05)\end{array}$ \\
\hline Rule of law (higher = better) & $\begin{array}{l}-0.03 \\
(0.03)\end{array}$ & $\begin{array}{l}-0.04 \\
(0.03)\end{array}$ & $\begin{array}{l}0.00 \\
(0.04)\end{array}$ \\
\hline $\begin{array}{l}\text { Ethno-linguistic fractionalization } \\
\text { (high = fractional) }\end{array}$ & $\begin{array}{c}1.2 \\
(1.2)\end{array}$ & $\begin{array}{c}2.5 \\
(1.5)\end{array}$ & $\begin{array}{l}7.5^{\star \star} \\
(2.6)\end{array}$ \\
\hline $\begin{array}{l}\text { Ethnic fractionalization } \\
\text { (high = fractionalized) }\end{array}$ & $\begin{array}{c}0.01 \\
(0.01)\end{array}$ & $\begin{array}{l}-0.00 \\
(0.01)\end{array}$ & $\begin{array}{l}0.00 \\
(0.02)\end{array}$ \\
\hline $\begin{array}{l}\text { Linguistic fractionalization } \\
\text { (high = fractional) }\end{array}$ & $\begin{array}{c}0.01 \\
(0.01)\end{array}$ & $\begin{array}{c}0.01 \\
(0.01)\end{array}$ & $\begin{array}{l}0.00 \\
(0.02)\end{array}$ \\
\hline $\begin{array}{l}\text { Religious fractionalization } \\
\text { Alesina et al. (2003) (high = fractional) }\end{array}$ & $\begin{array}{l}-0.01 \\
(0.01)\end{array}$ & $\begin{array}{r}0.02^{*} \\
(0.01)\end{array}$ & $\begin{array}{l}0.03^{* *} \\
(0.01)\end{array}$ \\
\hline
\end{tabular}

Notes: 1. Coefficients recorded are for the natural logarithm of population.

2. Robust standard errors (clustered by countries) in parentheses; ${ }^{*}{ }^{* *}$ ) indicates different from zero at the 5 percent ( 1 percent) level.

3. Data includes up to 208 "countries" at 10-year intervals, from 1960 through 2000.

4. OLS controls include urbanization rate; population density; landlocked dummy; island dummy; log of latitude (kilometers from equator); regional dummies for developing countries from Latin America, Sub-Saharan Africa, East Asia, South Asia, Europe-Central Asia, Middle East-North Africa; high-income country dummy; language dummies for English, French, German, Dutch, Portuguese, Spanish, Arabic, and Chinese; post-World War II country dummy; dummy for countries created between 1800 and 1945; dependency dummy, OPEC dummy; COMECON dummy; and dummies for countries that are all or partly tropical/arid/ monsoonal/temperate. Year effects (intercepts) also included.

5. IV uses log total area as an IV for log population; density is dropped from controls. 
multivariate model; and the "IV with controls" model that uses IVs instead of OLS.

I chose a large number (29) of controls. They include the urbanization rate; population density (which is dropped for the IV results); a binary dummy variable that is one for landlocked countries and zero otherwise; a similarly constructed island-nation dummy; the log of latitude (kilometers from the equator); regional dummies for developing countries from (1) Latin America, (2) Sub-Saharan Africa, (3) East Asia, (4) South Asia, (5) Europe-Central Asia, and (6) Middle East-North Africa; a high-income country dummy; language dummies for countries that speak (1) English, (2) French, (3) German, (4) Dutch, (5) Portuguese, (6) Spanish, (7) Arabic, and (8) Chinese; a dummy for countries created after World War II; a dummy for countries created between 1800 and 1945; a dummy for dependencies (like Macao), an OPEC dummy; a COMECON dummy; and dummies for countries that are all or partly (1) tropical, (2) arid, (3) monsoonal, and (4) temperate. These controls represent key geographic, linguistic, and political attributes, which might affect economic outcomes. Controlling for these endowments enables us to see if size has an additional effect on outcomes, holding such things constant. ${ }^{12}$

The "simple" results in the middle column of Table 1 indicate that there is essentially no simple link between country population and the 19 measures of economic and social well-being listed in the left-most column. The only exception (recorded in bold for emphasis) is the level of civil rights. Since lower numerical values of civil (and political) rights indicate more freedom and the coefficient is positive, this indicates that larger countries have systematically fewer civil rights. No other national scale effects are significantly different from zero at conventional levels. This is perhaps unsurprising, since the results are closely linked to the regression lines plotted in the figures. ${ }^{13}$

How does adding the many controls affect the results? Very little. The extra controls sop up variation in the data and improve the prevision of the size effect estimates somewhat when OLS is used (you can see this with the lower standard errors in the middle column). The effect of country size on real output was estimated with OLS without controls to be -0.07 but not significantly different from zero; when controls are added, the coefficient is still -0.07 but is now significantly different from zero at the 5 percent level. Size is also estimated to increase religious fractionalization, and the effect is different from zero at the 5 percent level..$^{14}$

The IV results are similar. The effect on polity is now positive and significantly different from zero; larger countries appear to be more democratic. The finding that larger countries are more religiously heterogeneous is robust to the exact choice

12. I have also experimented with adding controls for contiguity to countries that are large in either population or GDP; neither makes any substantial change to the results described below. Further, it makes essentially no difference to the negative results of the middle column of Table 1 if one adds extra controls for (1) the (10-year) lagged natural logarithm of real GDP per capita; (2) the (10-year) population growth rate; and (3) ethno-linguistic diversity simultaneously with lagged log real GDP per capita.

13. They are not identical, since the figures portray data from a single year (usually 2000), whereas Table 1 exploits all available data.

14. I have also added a number of interactions between size and other regressors (and regressands) to the regressions; these tend not to change the quantitative estimates of the size effect very much. I thank Naohiko Baba for this suggestion. Further, adding a quadratic term in $\log$ population also makes almost no difference to the results. 
of estimator when controls are included. And while the IV results do not show that either ethnic or linguistic fractionalization is significantly affected by size, the older ethno-linguistic fractionalization measure is now strongly positive linked to size.

Still, overall the evidence of any substantial national size effect is weak. Of the $(3 \times 19=) 57$ coefficients recorded in Table 1 , one might be expected to be different from zero at the 1 percent level even if all were actually zero, and another two at the 5 percent level. I conclude that the more rigorous statistical exercise conducted in this section confirms the simple graphical approach of Section III. The absence of a national scale effect is consistent with the hypothesis that countries seem to experience approximately constant returns to scale in producing not only GDP but also other social phenomena.

\section{Conclusion}

In this paper, I have searched for signs that larger countries are systematically different from small nations. Much economics incorporates the idea of returns to scale, so that it is cheaper to produce for a larger market than for a smaller one. This notion is fundamental to Adam Smith's The Wealth of Nations as well as much more recent economics, and implies that productivity and output per head should be higher in countries with more people. Large countries may also be more efficient at producing public goods such as health and education. On the other hand, larger countries may have disadvantages too, chiefly in the form of decreased social cohesion that results from a more diverse citizenry. In this paper, I have searched for empirical evidence on these theoretical notions.

I find little evidence for any of these ideas; in practice, there seems to be no obvious economic or social cost or benefit to country size. This is consistent with conventional wisdom; if countries with more people offered a systematically higher quality of life, smaller countries would be queuing up to join them. The fact that there is no obvious relationship between the number of people living in a country and the quality of its health, education, social, or economic systems is also reassuring from a policy viewpoint. It means that there is no clear benefit or cost to national size, and thus no argument for either expanding or contracting a typical country. This is bad news for economic theorists. Then again, that (small) cost is probably more than offset by the fact that this paper has undermined a potentially serious argument for imperialists and secessionists worldwide. 


\section{APPENDIX: DATA}

\section{Appendix Figure 1 Income and Land Size}

Log real GDP per capita (PPP) in 2000

11

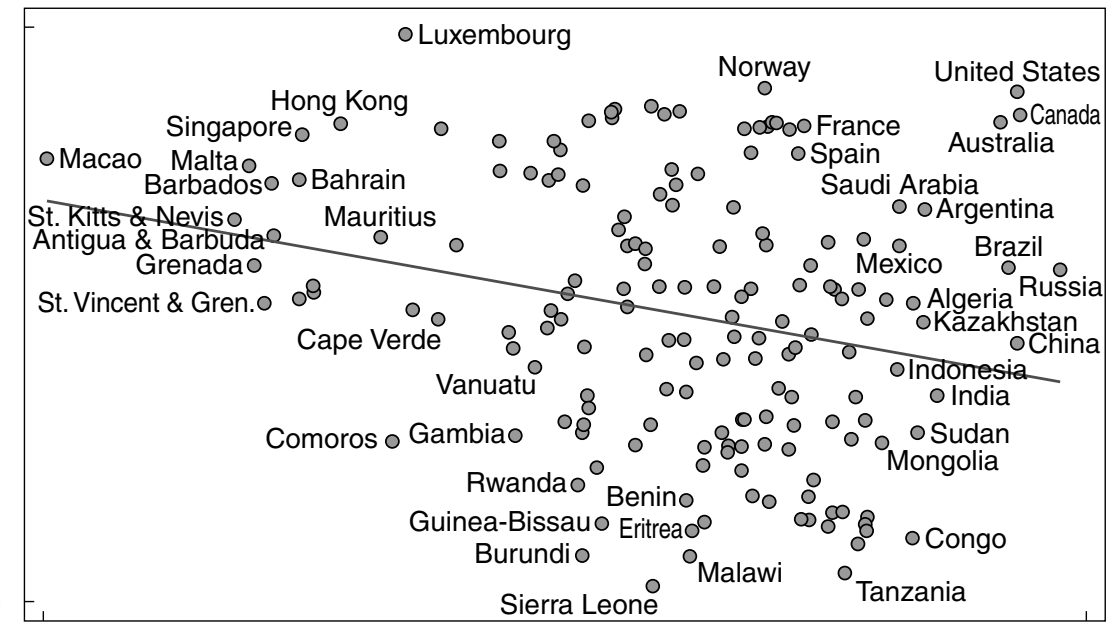

3

\section{Appendix Figure 2 Income and Country Size, with 29 Controls}

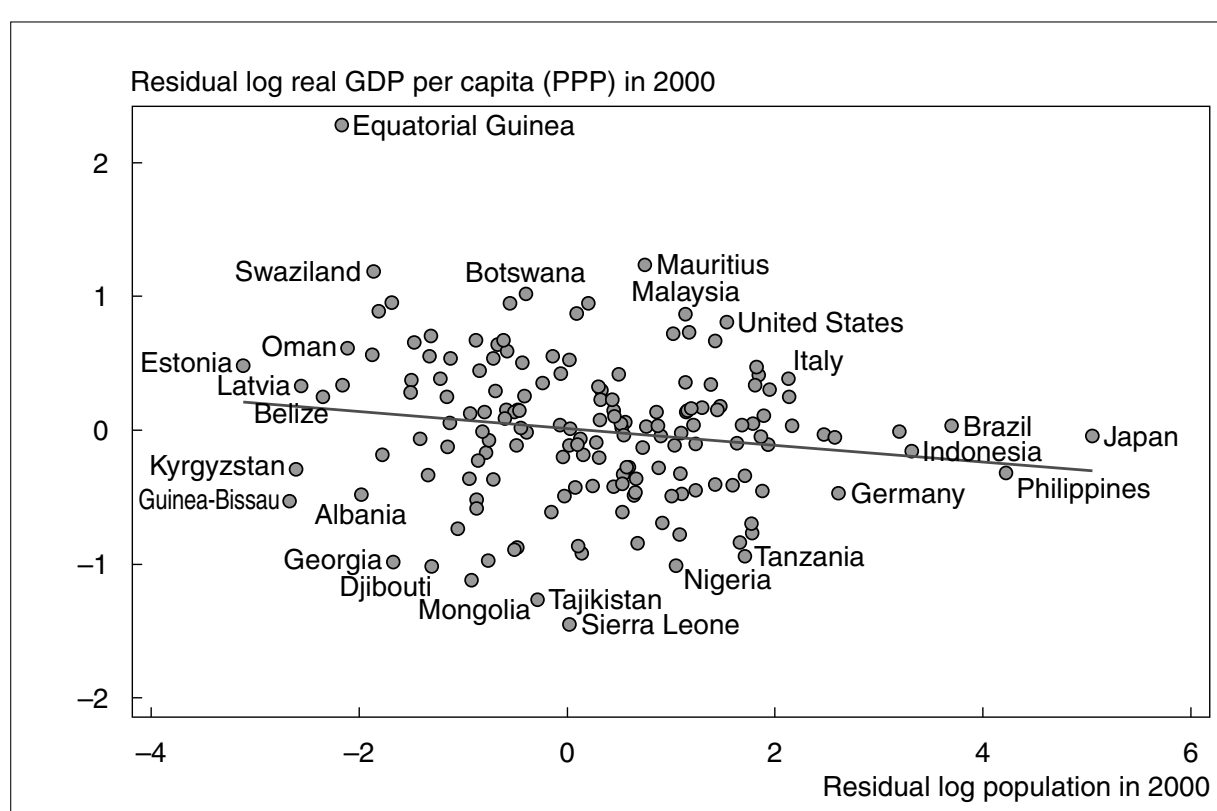


Appendix Table 1 List of "Countries"

\begin{tabular}{|c|}
\hline Afghanistan \\
\hline Albania \\
\hline Algeria \\
\hline American Samoa \\
\hline Andorra \\
\hline Angola \\
\hline Antigua \& Barbuda \\
\hline Argentina \\
\hline Armenia \\
\hline Aruba \\
\hline Australia \\
\hline Austria \\
\hline Azerbaijan \\
\hline Bahamas, The \\
\hline Bahrain \\
\hline Bangladesh \\
\hline Barbados \\
\hline Belarus \\
\hline Belgium \\
\hline Belize \\
\hline Benin \\
\hline Bermuda \\
\hline Bhutan \\
\hline Bolivia \\
\hline Bosnia-Herzegovina \\
\hline Botswana \\
\hline Brazil \\
\hline Brunei \\
\hline Bulgaria \\
\hline Burkina Faso \\
\hline Burundi \\
\hline Cambodia \\
\hline Cameroon \\
\hline Canada \\
\hline Cape Verde \\
\hline Cayman Islands \\
\hline Central African Rep. \\
\hline Chad \\
\hline Channel Islands \\
\hline Chile \\
\hline China \\
\hline Colombia \\
\hline Comoros \\
\hline Congo, Dem. Rep. \\
\hline Congo, Rep. \\
\hline Costa Rica \\
\hline Côte d'Ivoire \\
\hline Croatia \\
\hline Cuba \\
\hline Cyprus \\
\hline Czech Republic \\
\hline Denmark \\
\hline Djibouti \\
\hline Dominica \\
\hline Dominican Republic \\
\hline Ecuador \\
\hline Egypt, Arab Rep. \\
\hline El Salvador \\
\hline
\end{tabular}

\begin{tabular}{|c|}
\hline Equatorial Guinea \\
\hline Eritrea \\
\hline Estonia \\
\hline Ethiopia \\
\hline Faeroe Islands \\
\hline Fiji \\
\hline Finland \\
\hline France \\
\hline French Polynesia \\
\hline Gabon \\
\hline Gambia, The \\
\hline Georgia \\
\hline Germany \\
\hline Ghana \\
\hline Greece \\
\hline Greenland \\
\hline Grenada \\
\hline Guam (U.S.) \\
\hline Guatemala \\
\hline Guinea \\
\hline Guinea-Bissau \\
\hline Guyana \\
\hline Haiti \\
\hline Honduras \\
\hline Hong Kong, China \\
\hline Hungary \\
\hline Iceland \\
\hline India \\
\hline Indonesia \\
\hline Iran, Islamic Rep. \\
\hline Iraq \\
\hline Ireland \\
\hline Isle of Man \\
\hline Israel \\
\hline Italy \\
\hline Jamaica \\
\hline Japan \\
\hline Jordan \\
\hline Kazakhstan \\
\hline Kenya \\
\hline Kiribati \\
\hline Korea, Dem. Rep. \\
\hline Korea, Rep. \\
\hline Kuwait \\
\hline Kyrgyz Republic \\
\hline Lao PDR \\
\hline Latvia \\
\hline Lebanon \\
\hline Lesotho \\
\hline Liberia \\
\hline Libya \\
\hline Liechtenstein \\
\hline Lithuania \\
\hline Luxembourg \\
\hline Macao, China \\
\hline Macedonia, FYR \\
\hline Madagascar \\
\hline Malawi \\
\hline
\end{tabular}

\begin{tabular}{|c|}
\hline Malaysia \\
\hline Maldives \\
\hline Mali \\
\hline Malta \\
\hline Marshall Islands \\
\hline Mauritania \\
\hline Mauritius \\
\hline Mayotte \\
\hline Mexico \\
\hline Micronesia, Fed. Sts. \\
\hline Moldova \\
\hline Monaco \\
\hline Mongolia \\
\hline Morocco \\
\hline Mozambique \\
\hline Myanmar \\
\hline Namibia \\
\hline Nepal \\
\hline Netherlands \\
\hline Netherlands Antilles \\
\hline New Caledonia \\
\hline New Zealand \\
\hline Nicaragua \\
\hline Niger \\
\hline Nigeria \\
\hline Northern Mariana Isl. \\
\hline Norway \\
\hline Oman \\
\hline Pakistan \\
\hline Palau \\
\hline Panama \\
\hline Papua New Guinea \\
\hline Paraguay \\
\hline Peru \\
\hline Philippines \\
\hline Poland \\
\hline Portugal \\
\hline Puerto Rico (U.S.) \\
\hline Qatar \\
\hline Romania \\
\hline Russian Federation \\
\hline Rwanda \\
\hline Samoa \\
\hline San Marino \\
\hline Sâo Tomé \& Principe \\
\hline Saudi Arabia \\
\hline Senegal \\
\hline Serbia \& Montenegro \\
\hline Seychelles \\
\hline Sierra Leone \\
\hline Singapore \\
\hline Slovak Republic \\
\hline Slovenia \\
\hline Solomon Islands \\
\hline Somalia \\
\hline South Africa \\
\hline Spain \\
\hline Sri Lanka \\
\hline
\end{tabular}

\begin{tabular}{|c|}
\hline St. Kitts \& Nevis \\
\hline St. Lucia \\
\hline St. Vincent \& Gren. \\
\hline Sudan \\
\hline Suriname \\
\hline Swaziland \\
\hline Sweden \\
\hline Switzerland \\
\hline Syrian Arab Republic \\
\hline Tajikistan \\
\hline Tanzania \\
\hline Thailand \\
\hline Timor-Leste \\
\hline Togo \\
\hline Tonga \\
\hline Trinidad \& Tobago \\
\hline Tunisia \\
\hline Turkey \\
\hline Turkmenistan \\
\hline Uganda \\
\hline Ukraine \\
\hline United Arab Emirates \\
\hline United Kingdom \\
\hline United States \\
\hline Uruguay \\
\hline Uzbekistan \\
\hline Vanuatu \\
\hline Venezuela, RB \\
\hline Vietnam \\
\hline Virgin Islands (U.S.) \\
\hline West Bank \& Gaza \\
\hline Yemen, Rep. \\
\hline Zambia \\
\hline Zimbabwe \\
\hline
\end{tabular}




\section{Appendix Table 2 Data Sources}

Alesina et al. (2003) (http://www.stanford.edu/ wacziarg/downloads/fractionalization.xls): ethnic fractionalization; linguistic fractionalization; religious fractionalization.

CIA World Factbook (http://www.cia.gov/cia/publications/factbook/): independence date; geographic and linguistic controls.

Collier and Hoeffler (2004) (http://users.ox.ac.uk/ ball0144/g\&g.zip): ethno-linguistic fractionalization.

Freedom House (http://www.freedomhouse.org/): political and civil rights.

Kaufmann, Kraay, and Zoido-Lobaton (1999) (http://www1.worldbank.org/publicsector/ indicators.htm): government effectiveness; rule of law.

Polity IV (http://www.cidcm.umd.edu/inscr/polity/): polity.

UNDP (http://hdr.undp.org/statistics/data/): human development index; life expectancy at birth.

World Development Indicators (http://www.worldbank.org/data/wdi2005/index.html): population; real GDP per capita; vehicles; televisions; telephones; infant mortality; literacy rate; primary school completion rate; secondary school enrollment rate; density; urbanization; high-income and regional groupings.

\section{Appendix Table 3 Descriptive Statistics for Key Variables}

\begin{tabular}{|l|r|r|r|r|r|}
\hline & Obs. & Mean & \multicolumn{1}{c|}{ Std. dev. } & \multicolumn{1}{c|}{ Min } & Max \\
\hline Log population & 1,040 & 14.7 & 2.3 & 8.9 & 21.0 \\
\hline Log real GDP per capita, PPP & 458 & 8.4 & 1.1 & 6.1 & 10.9 \\
\hline Life expectancy at birth & 344 & 61.8 & 12.6 & 32.4 & 81.6 \\
\hline Infant mortality rate & 872 & 6.9 & 5.4 & 0.3 & 28.5 \\
\hline Literacy rate & 477 & 69.1 & 26.1 & 5.7 & 99.8 \\
\hline Primary school completion rate & 202 & 79.1 & 26.6 & 12.0 & 121.0 \\
\hline Secondary school enrollment rate & 303 & 63.9 & 33.0 & 4.7 & 160.7 \\
\hline Human development index & 367 & 67.0 & 19.0 & 26.0 & 95.0 \\
\hline Vehicles/person & 193 & 0.17 & 0.19 & 0.007 & 0.76 \\
\hline Televisions/person & 554 & 0.20 & 0.21 & 0.0 & 1.11 \\
\hline Telephones/person & 172 & 0.13 & 0.16 & 0.0 & 0.68 \\
\hline Polity & 30 & 0.1 & 7.6 & -10.0 & 10.0 \\
\hline Political rights & 501 & 3.9 & 2.3 & 1.0 & 7.0 \\
\hline Civil rights & 501 & 3.9 & 1.9 & 1.0 & 7.0 \\
\hline Government effectiveness & 184 & -0.0 & 1.0 & -2.6 & 2.5 \\
\hline Rule of law & 185 & -0.0 & 1.0 & -2.3 & 2.2 \\
\hline Ethno-linguistic fractionalization & 143 & 0.4 & 0.3 & 0.0 & 0.9 \\
\hline Ethnic fractionalization & 186 & 0.4 & 0.3 & 0.0 & 0.9 \\
\hline Linguistic fractionalization & 191 & 0.4 & 0.3 & 0.0 & 0.9 \\
\hline Religious fractionalization & 203 & 0.4 & 0.2 & 0.0 & 0.9 \\
\hline
\end{tabular}




\section{References}

Aghion, Philippe, and Peter Howitt, Endogenous Growth Theory, Cambridge, Massachusetts: The MIT Press, 1998.

Alesina, Alberto, Arnaud Devleeschauwer, William Easterly, Sergio Kurlat, and Romain Wacziarg, "Fractionalization," Journal of Economic Growth, 8 (2), 2003, pp. 155-194. , and Enrico Spolaore, The Size of Nations, Cambridge, Massachusetts: The MIT Press, 2003.

Barro, Robert J., and Xavier Sala-i-Martin, Economic Growth, New York: McGraw-Hill, 1995.

Collier, Paul, and Anke Hoeffler, "Greed and Grievance in Civil War," Oxford Economic Papers, 56 (4), 2004, pp. 563-595.

Drazen, Allan, Political Economy in Macroeconomics, Princeton: Princeton University Press, 2000.

Fujita, Masahisa, Paul Krugman, and Anthony Venables, The Spatial Economy, Cambridge, Massachusetts: The MIT Press, 1999.

Helpman, Elhanan, and Paul R. Krugman, Market Structure and Foreign Trade, Cambridge, Massachusetts: The MIT Press, 1985.

Jones, Charles I., "Growth: With or Without Scale Effects?” American Economic Review, 89 (2), 1999, pp. 139-144.

Kaufmann, Daniel, Aart Kraay, and Pablo Zoido-Lobaton, "Governance Matters," Policy Research Working Paper No. 2196, World Bank, 1999.

Mauro, Paolo, "Corruption and Growth," Quarterly Journal of Economics, 110 (3), 1995, pp. 681-712.

Olson, Mancur, The Rise and Decline of Nations, New Haven: Yale University Press, 1982.

Perkins, Dwight H., and Moshe Syrquin, "Large Countries: The Influence of Size," in Hollis B. Chenery and T. N. Srinivasan, eds. Handbook of Development Economics, Volume II, Amsterdam: Elsevier, 1989.

Rose, Andrew K., "Size Really Doesn't Matter: In Search of a National Scale Effect," Journal of the Japanese and International Economies, 2006 (forthcoming). 